\title{
Alien crayfish species in Latvian inland waters
}

\author{
Jānis Birzaks, Artūrs Škute* \\ University of Daugavpils, Vienības 13, Daugavpils LV-5401, Latvia \\ *Corresponding author, E-mail: arturs.skute@du.lv
}

\begin{abstract}
Survey of data on Latvian freshwater crayfish species distribution and occurrence in different waterbodies (404 lakes, 368 rivers and 47 reservoirs, nine quarry reservoirs) across the territory in the last decades from 1988 to 2018 were performed with the aim to compare field data with previous research, inquiries and grey data. The most frequently occurring species was native noble crayfish Astacus astacus and the introduced narrow-clawed crayfish Astacus leptodactylis, with incidence of 26 and 5\% from surveyed waterbodies, respectively. The invasive alien crayfish species Orconectes limosus and Pacifastacus leniusculus occured in 23 (2.8\%) and 10 (1.2\%) of waterbodies, respectively. The history of invasion of alien crayfish species was analysed. Survey results demonstrated that in the last decades noble crayfish occurrence decreased, or their presence was not detected due to low population density. The occurrence of other species, especially invasive spiny-cheek crayfish, was increasing.
\end{abstract}

Key words: alien species, crayfish, Latvia.

\section{Introduction}

The number of native crayfish populations and their abundance are decreasing throughout Europe because of anthropogenic pressures on freshwater habitat (including morphological modifications, fragmentation, land use and urbanisation, pollution and eutrophication), overfishing and spread of invasive alien species (Edgerton et al. 2004; Füreder et al. 2006).

One of the biggest threats for native crayfish in Europe is presence of alien (non-indigenous) crayfish species, which were introduced in the previous century (Holdich et al. 2009). Two of them - spiny cheek crayfish (Orconectes limosus) and signal crayfish (Pacifastacus leniusculus) are present in Latvia (Aleksejevs 2006). These species are more adaptive and aggressive, and tolerant to crayfish plague, which is the reason for indigenous noble crayfish (Astacus astacus) and introduced narrow-clawed (Astacus leptodactylus) crayfish mass mortality. As invasive species, alien crayfish occupy suitable habitats and expand their distribution. Research in Europe has shown that there is a downward trend in native crayfish species distribution range, occurrence and population density (Holdich 2002; Holdich et al. 2009).

The goal of this study was to collate the information about the occurrence and distribution of non-indigenous crayfish species in inland waters of Latvia, which was available in the literature and archival materials, in comparison with data obtained by the authors in field surveys from 1988 to 2018.

\section{Methods}

The evaluation of the occurrence and distribution of crayfish stocks was performed from 1988 to 2018, in various seasons from April to November, using traps, seine and electrofishing gear in 404 lakes (20\% from the total number), 35 reservoirs on rivers ( $7 \%$ from the total number), nine quarry reservoirs and 368 rivers (3\% from the total number).

The occurrence and distribution of crayfish stocks was undertaken in various seasons from April to November, using cylindrical traps with two conical entrances. The length of traps was $55 \mathrm{~cm}$ with diameter $30 \mathrm{~cm}$ with 10 $\mathrm{mm}$ square mesh. Fresh cyprinids (often roach and bream), which came from the same waterbody where traps were placed, were used as bait.

Crayfish traps were set along the coastal zone of lakes in lines of five gears in the studied reach from the evening before sunset, and removed and checked at sunrise. Five to twenty traps were usually used, depending on lake size and habitat suitability, but in some cases cray fishing effort increased up to 120 traps.

In some cases, when the crayfish had not been caught by the traps, they were detected by beach seining (opening of the seine was $10 \mathrm{~m}$ and mesh size in code-end was $5 \mathrm{~mm}$ square mesh) or in gill nets used for fishing.

Crayfish in rivers were mainly found during fish monitoring, which was undertaken using a direct current electro-fishing gear SE Electrofishers Standard 300 with output voltage $300 \mathrm{~V}$ and current $10 \mathrm{~A}$ supplied by $2 \mathrm{~kW}$ generator. 


\section{Results and discussion}

Narrow-clawed crayfish, signal crayfish and spiny-cheek crayfish were found in 37 lakes, four reservoirs on rivers, four quarry reservoirs and 31 rivers (Table 1). The native crayfish distribution was the same as historical distribution and occurrence. Due to legal and illegal introduction and natural dispersal, the range of invasive crayfish species expansion has been increasing in Latvian inland waters.

Crayfish have been found in many Latvian lakes and rivers in the 1930-ies and 1950-ies, but their abundance and species composition were not specified (Bērziņš 1936; Kotov et al. 1958). Later, from 1960 -ies up to now, species have been identified. According to the variety of sources of information such as research reports, cray fisheries logbooks, questionnaires and grey information from 1951 to 2018 , crayfish were found in 566 lakes, 49 reservoirs on rivers, 24 quarry reservoirs and 211 rivers in total.

According to the field survey, European crayfish species - noble crayfish (Astacus astacus) and narrowclawed crayfish (Astacus leptodactylus) - occur more frequently in Latvian inland waters (Table 1). The noble crayfish is obviously the only local species in Latvian waters. In surveys conducted from 1988 to 2018, noble crayfish was found in 158 lakes, 52 rivers, six reservoirs on rivers and five quarry reservoirs throughout the territory of Latvia, in all of the largest river basins (Table 1).

The character of distribution of narrow-clawed crayfish suggests that, historically, this species have not been a native in Latvia. Narrow-clawed crayfish have not been found further to the north from Latvia in Estonia (Paaver, Hurt 2010; Kouba et al. 2014). The presumed native range of the species includes Pontocaspian river basins (Kouba et al. 2014). In Belarus, narrow-clawed crayfish is considered a local species that is increasing in area of distribution northward (Šteinfeld 1957; Aklehnovich, Razlutskij 2013). The species in Latvia is not considered invasive, mainly due to its European origin, being introduced in Latvia and Lithuania relatively recently (Holdich et al. 2009).

In neighbouring Estonia and Lithuania, noble crayfish is the only local species (Arbačiauskas et al. 2012; Burba 1994; Paaver, Hurt 2010; Kouba et al. 2014; Taugbøl 1998). In Belarus, the noble crayfish populations have co-existed with narrow-clawed crayfish (Šteinfeld 1957; Aklehnovich,
Razlutskij 2013). Also in Latvia, in Lake Vaidava, these species are found together.

The distribution of narrow-clawed crayfish in neighbouring countries (Arbačiauskas et al. 2012; Kouba et al.2014) provides evidence that human facilitated spread of the species in inland waters of Latvia has occurred. Based on unofficial information, the unsanctioned spread of narrow-clawed crayfish is also taking place at present.

Signal crayfish (Pacifastacus leniusculus) was introduced in Latvia from Lithuania in 1983 and 1984 and released in Primma Lake between 1983 and 1985 (Mjasischev 1991). Individuals of the species were raised in a fish farm on the Gauja's tributary, the river Brasla, from which they entered this river.

At first, signal crayfish have successfully acclimatized and formed a naturally reproducing population in Primma Lake. They may possibly have reached the adjacent Kliķu Lake through the ditch system and along the Korge River into the river Salaca and their tributaries, where a particularly large population of signal crayfish has developed. The legal crayfishery in the Salaca River, which commenced in 2007 in order to decrease the population size, obviously facilitated the process of invasion even more due to human facilitated spread of species across the country. Individuals of the species have been found in natural water bodies only in the Salaca and the Gauja rivers basins, but, based on unofficial information, they were also released in the lower part of the Daugava River basin in the Riga city territory, and also in two small rivers flowing into the East part of the Gulf of Riga. Owners of the private lakes and ponds are interested in their illegal introduction, which obviously will gradually increase their distribution area. It should be noted that the mass mortality of the signal crayfish, as opposed to the noble and narrow-clawed crayfish, has not been observed in Latvia.

Spiny-cheek crayfish (Orconectes limosus) was recognized as a new species in Latvia for the first time in 2005 , in the Lielupe River. Based on unofficial information, it has been found in Latvia since at least the 1990-ies. The entry of the spiny-cheek crayfish into Latvia is unclear. It can be found in the Daugava River, as well as the Sventäja and the Venta rivers, the Lielupe River tributaries and their tributaries, the Mēmele and the Mūsa rivers, which originate in Lithuania. All the above-mentioned rivers,

Table 1. Occurrence of crayfish species in inland waters of Latvia according to the survey from 1988 to 2018

\begin{tabular}{lcccc} 
Waterbody type & \multicolumn{2}{c}{ European species } & \multicolumn{2}{c}{ Invasive alien species } \\
\cline { 2 - 5 } & $\begin{array}{c}\text { Astacus astacus } \\
\text { (noble crayfish) }\end{array}$ & $\begin{array}{c}\text { Astacus leptodactylus } \\
\text { (narrow-clawed crayfish) }\end{array}$ & $\begin{array}{c}\text { Pacifastacus leniusculus } \\
\text { (signal crayfish) }\end{array}$ & $\begin{array}{c}\text { Orconectes limosus } \\
\text { (spiny-cheek crayfish) }\end{array}$ \\
Lakes & 158 & 33 & 1 & 3 \\
Reservoirs on rivers & 6 & 3 & & 1 \\
Quarry reservoirs & 5 & 2 & 9 & 2 \\
Rivers & 52 & 4 & 10 & 18 \\
Total & 221 & 42 & 24
\end{tabular}




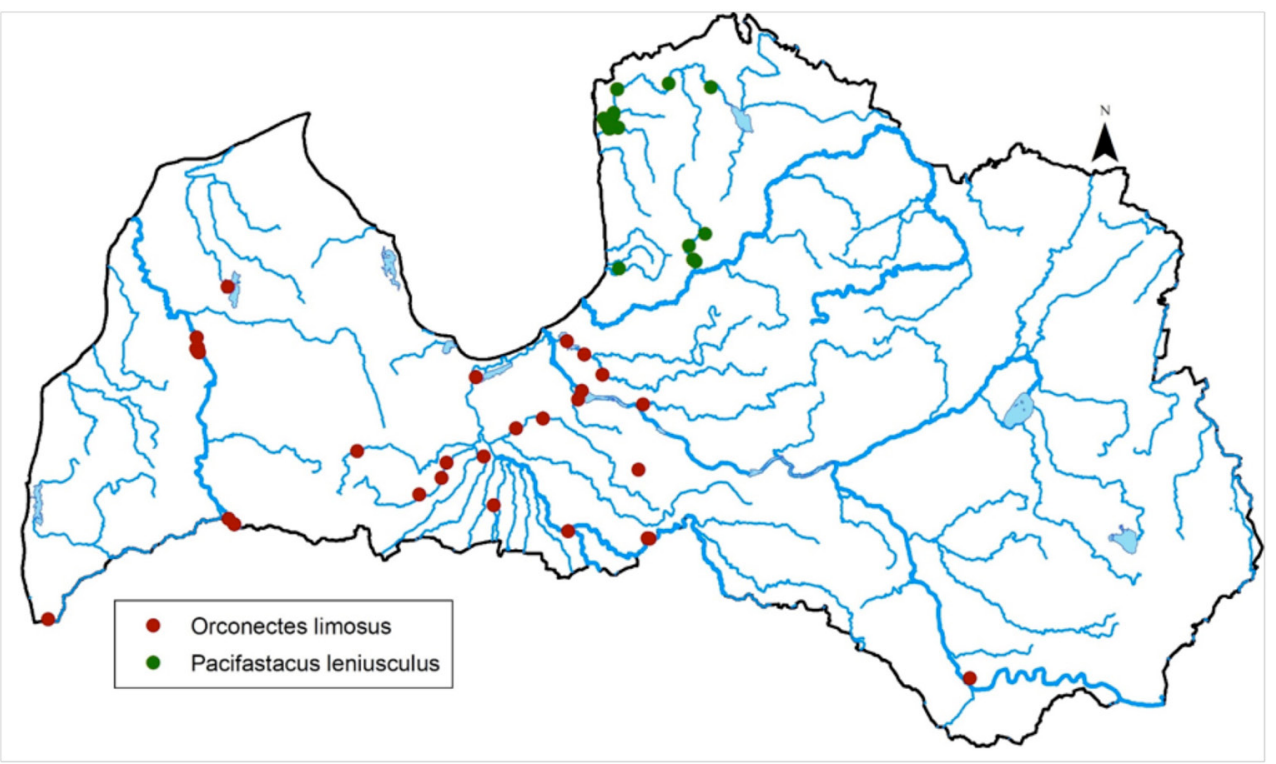

Fig. 1. Distribution of alien crayfish species in Latvia.

except the Daugava, start in Lithuania. In the lower part, the river Daugava is connected by the river Lielupe through an old river-bed.

The spiny-cheek crayfish can also be found in Lithuania, in the upper reaches of the rivers of the Lielupe basin and the Venta River (Arbačiauskas et al. 2012), from where it may possibly have migrated northward to Latvia.

Until 2018, individuals of spiny-cheek crayfish have been caught during test fishing in three lakes, 18 rivers, two quarry reservoirs and one river reservoir (Table 1, Fig. 1). It can be seen from fish monitoring data in rivers that the number of the sites where spiny-cheek crayfish were found in rivers has been increasing in recent years. Thus, in 2005, one site with individuals of the species was found in the Lielupe River, but 18 and eight findings in total were in 2015 and 2016, respectively.

From 2006 to 2018, the spiny-cheek crayfish was found in two lakes connected to the lower reaches of the Daugava River, but in 2016 it was found in Lake Usma (the river Irbe basin), which is located inland and is not connected with the river basins in which it was found before. Its rapid spread has been observed in the Venta River, where it was found for the first time near the Lithuanian border in 2011, but it could already be found in a $123 \mathrm{~km}$ long section downstream in 2016 - 2018, and it was spreading with the rate of $20 \mathrm{~km}$ per year. A similar rate of invasive crayfish spread was also mentioned in studies carried out in other countries (Puky, Schad 2006; Aklehnovich, Razlutskij 2013). In 2015, spiny-cheek crayfish was found in a pond in the city of Daugavpils, which is situated $230 \mathrm{~km}$ from Riga and 30 from the border of Belarus, or more than $200 \mathrm{~km}$ from the closest location of occurrence. The species could reach this waterbody only as a result of human facilitated spread, to serve as a source of alien species harvesting and distribution. The spiny-cheek crayfish was found in the
Sventāja, a river flowing along the Latvian-Lithuanian border. It is also likely to reach the Bārta River, which starts in the territory of Lithuania, but in Latvia flows into Lake Liepāja.

Overall, it appears that the spiny-cheek crayfish is spreading rapidly in waters between the Latvia-Lithuania border and the rivers Venta and Daugava; in fact, in three of the four Latvian river basin districts.

Since 2013, legal catching of the spiny-cheek crayfish has been permitted in unlimited numbers in the lower reaches of Daugava, the Lielupe and the Venta rivers (Anonymous 2015), which will probably facilitate the unsanctioned dissemination process of the spiny cheek crayfish even more. Based on unverified information, it can be found in the south-eastern part of Latvia as well, but it has not been recorded in waters of the Daugava River basin in Belarus (Aklehnovich, Razlutskij 2013).

Crayfish habitats in rivers are fragmented by hydropower- and mill-dams in the rivers. Lake outlets in many cases are blocked by stationary eel traps or water level and discharge regulation facilities, or their level has been lowered for agricultural or forest land reclamation. Altogether, 706 manmade obstacles are located in the rivers or their outlets from lakes. This situation increases the fragmentation of crayfish populations, preventing them from moving upstream.

Invasive crayfish species, especially the spiny-cheek crayfish, is tolerant to low water quality. The presence of this species was related significantly with nutrient enrichment (particularly ammonium, nitrite and iron) (Svobodova et al. 2012). In Latvia, it is found and widely distributed in the river Lielupe, which is highly affected by anthropogenic impact (Anonymous 2015).

Just 30 years ago, Latvian inland waters were inhabited only by the two European crayfish species. Since legal and 
illegal introduction and due to natural dispersal, the range of invasive crayfish species expansion has been increasing, as throughout Europe (Jussila et al. 2016). It has been observed that native crayfish species are displaced by the invasion of signal crayfish or spiny-cheek crayfish (Holdich, et al. 2009; Hudina et al. 2017; Maguire et al. 2018). These species seem to be the primary reservoir of crayfish plague (Kozubikova et al. 2008).

Our findings showed that, in general, the native crayfish distribution was the same as historical distribution and occurrence. However, individual, local populations have been lost or have become insignificant as a result of anthropogenic transformation of habitats, low water quality and invasion of invasive crayfish species. The adopted management measures have proved ineffective. The harvesting of noble crayfish is prohibited, except for waterbodies by crayfisheries with a special fee (named licensed fisheries) and with limited effort and bag limit. These measures should increase noble crayfish abundance and protect them from overexploitation. However, in water bodies with large populations, mass mortality of noble crayfish and narrow-clawed crayfish are observed most often. Changes in the distribution and occurrence of invasive crayfish species indicate that their unauthorized restocking and natural migration in the river network is continuing.

Measures of preservation of self-sustainable indigenous crayfish populations is one of priorities in protection of biodiversity in inland waters. This study suggests that it would be necessary to develop a national-level strategy for limitation of the non-indigenous crayfish species population.

\section{References}

Anonymous. 2015a. The rules of angling, crayfishing and spear fishing. Available from: https://likumi.lv/ta/id/279205makskeresanas-vezosanas-un-zemudens-medibu-noteikumi /viewed 02.12.2018/

Anonymous. 2015b. The river basin districts management plans 2015 - 2021. Available from: https://www.meteo.lv/ lapas/vide/udens/udens-apsaimniekosana-/upju-baseinuapsaimniekosanas-plani-/upju-baseinu-apsaimniekosanasplani?\&id=1107\&nid=424/viewed 02.12.2018/

Aleksejevs E. 2006. Latvian crayfish. Latvian fisheries yearbook 2006. $10^{\text {th }}$ year, pp. 73-81. /in Latvian/

Aklehnovich A., Razlutskij V. 2013. Distribution and spread of spiny-cheek crayfish Orconectes limosus (Rafinesque, 1817) in Belarus. BioInvas. Rec. 2/3: 221-225.

Arbačiauskas K., Višinskiene G., Smilgevičiene S., Rakauskas V. 2012. Non-indigenous macroinvertebrate species in Lithuanian fresh waters, Part 1: Distributions, dispersal and future. Knowl. Manage. Aquat. Ecosyst. 402: 1-18.

Bērziņš B. 1936. Latvian crayfish. In: Malta N., Galenieks P. (eds) Latvian Land, Nature and People. Vol. 2. Latvian Nature. Rīga, pp. 624-630. /in Latvian/

Burba A. 1994. Facts about Crayfish in Lithuania. Nordic J. Freshwat. Res. 69: 170-172.
Cukerzis J.M. 1989. Perspective crayfish species aquaculture in North west region of USSR. Proceedings of Gosniorh 300: 5-10. /in Russian/

Edgerton B., Henttonen P., Jussila J., Mannonen A., Passonen P., Taugbøl T., Edsman L., Souty-Grosset C. 2004. Understanding the causes of disease in European freshwater crayfish. Conserv. Biol. 18: 1466-1474.

Füreder L., Edsman L., Holdich DM., et al. 2006. Indigenous crayfish habitat and threats. In: Souty- Grosset C., Holdich DM., Noël P., Reynold J. D., Haffner P. (eds) Atlas of Crayfish in Europe. Muséum national d'Histoire naturelle, Paris, pp. 25-47.

Holdich D.M. 2002. Distribution of crayfish in Europe and some adjoining countries. Bull. Fr. Pêche Piscic. 367: 611-650.

Holdich D.M., Reynolds J.D., Souty-Grosset C., Sibley P,J. 2009. A review of the ever increasing threat to European crayfish from non-indigenous crayfish species. Knowl. Manage. Aquat. Ecosyst. 11: 394-395.

Jurane A.D. 1967. Distribution of River crayfish and its stocks in water bodies of Latvian SSR. Resources of North-West inland waters. Proceedings of the Karelian department of Gosniorh 5: 219-223. /in Russian/

Jurane A.D., Dzene I,J. 1969. Distribution of river crayfish and its stocks in water bodies of Latvian SSR. Proceedings of a XIV conference of investigations of Baltic inland water, pp. 51-55. I in Russian/

Jussila J., Maguire I., Kokko H., Makkonen J. 2016. Chaos and adaptation in the pathogen- host relationship in relation to the conservation. The case of the crayfish plague and the noble crayfish. In: Kawai T., Faulkes Z., Scholtz G. (eds.) Freshwater Crayfish - A Global Overview. Taylor and Francis, Boca Raton, pp. 246-275.

Kouba A., Petrusek A., Kozák P. 2014. Continental-wide distribution of crayfish species in Europe: update and maps. Knowl. Manage. Aquat. Ecosyst. 413: 1-31.

Kozubikova E., Filipova L., Kozak Z., Duriš Z., Martin M. P., Dieguez-Uribeondo J., Oidtmann B., Petrusek A. 2009. Prevalence of the crayfish plague pathogen Aphanomyces astaci in invasive American crayfishes in the Czech Republic. Conserv. Biol. 23: 1204-1213.

Maguire I., Klobučar G., Žganec K., Zelič M., Lucič A., Hudina S. 2018. Recent changes in distribution pattern of freshwater crayfish in Croatia - threats and perspectives. Knowl. Manage. Aquat. Ecosyst. 419: 2.

Mazitis Z. 1955. Crayfish breeding in Latvian SSR freshwater. Rìga, 42 p. /in Latvian/

Mazìtis Z. 1967. Crayfish and breeding of them. Rīga, 35 p. /in Latvian/

Mazītis Z. 1971. Selection and industrial breeding of crayfish. Rīga, 70 p. /in Latvian/

Mjasischev E.V. 1991. Acclimatization and experience of farming of American signal crayfish. In: Kalejs M et. al. (eds) Acquaculture in Baltic. Rìga, pp. 100-108. /in Russian/

Paaver T., Hurt M. 2010. Status and management of noble crayfish Astacus astacus in Estonia. Knowl. Manage. Aquat. Ecosyst. 18: 394-395.

Peay S., Füreder L. 2011. Two indigenous European crayfish under threat - how can we retain them in aquatic ecosystems for the future? Knowl. Manage. Aquat. Ecosyst. 401: 33.

Puky M., Schad P. 2006. Orconectes limosus colonises new areas fast along Danube in Hungary. Bull. Fr. Pêche Piscic. 380/381: 919-926-919. 
Rahmanov V. R. 1976. Biology and fishery of river crayfish in BSSR. Resources of inland waters of Pskov region. Proceedings of the Pskov's department of Gosniorh 5: 121-145. /in Russian/ Svobodova J., Douda K., Štambergova M., Picek J., Vlach P., Fischer D. 2012. The relationship between water quality and indigenous and alien crayfish distribution in the Czech
Republic: patterns and conservation implications. Aquat. Conserv. Mar. Freshwat. Ecosyst. 22: 776-786.

Šteinfeld L.A. 1957. Biology and fishery of river crayfish in BSSR. Proceedings of the Belorussian department of VNIORH 5: 118-137. /in Russian/ 